\title{
Effectiveness of an Instructional Program on Knowledge of Mastectomized Patients Regarding Lymphedema in Al-Amal National Hospital for Cancer Management
}

\author{
Wissam I. Wardia, MSc.N ${ }^{1}$, Dr. Wafaa M. A. Al-Attar,PhD ${ }^{2}$ \\ ${ }^{1}$ (Academic Nurse, Adults Nursing, College of Nursing, University of Baghdad, Iraq) \\ ${ }_{2}^{2}$ (Professor, Adults Nursing, National Cancer Research Center / University of Baghdad,Iraq)
}

\begin{abstract}
:
Objectives: The main aim of the study is to determine the effectiveness of an instructional program on knowledge of mastectomized patients regarding lymphedema.

Methodology: A quasi-experimental study was carried out at Al Amal National Hospital for Cancer Management from October $18^{\text {th }}, 2015$ to July10 ${ }^{\text {th }}, 2016$. The program and instruments were constructed by the researcher for the purpose of the study. Apurposive random sample comprised of (60) mastectomized patients was divided into two groups, study group consisted of (30) patients exposed to an instructional program and control group consisted of (30) patients were not exposed to the program. The study instrument is composed of three main parts: Part I. The socio- demographic characteristics of the patients, Part II. Clinical data of the patients, Part III. Knowledge of mastectomized patients regarding breast cancer related lymphedema which was consists of 60 items. Reliability of instrument was determined and the instrument validity was determined through a panel of experts. The analysis of the data that used was descriptive statistics and statistical inferential. In order to find the differences between the experimental group and the control group.

Results: The study findings indicated that here were highly significant differences between pre and post-tests in the experimental group in overall main domains regarding patient' knowledge concerning with breast cancer related lymphedema.

Conclusion: The study concluded that the effectiveness of an Instructional program regarding patient s' knowledge concerning breast cancer related lymphedema is positive at a high rate.

Recommendation: The researcher recommended encouraging nursing staff in the hospitals to participate in teaching the patients, providing, and maintaining the necessary information about breast cancer related lymphedema through lectures and continuous education to the patients.
\end{abstract}

Keywords: Instructional,Knowledge, Mastectomized, Lymphedema.

\section{Introduction}

Lymphedema is an abnormal accumulation of protein-rich fluid within the interstitial tissue that can occur after breast cancer (BC) surgery or radiation therapy. It is one of the most common complications after $\mathrm{BC}$ surgery, and approximately $15 \%$ to $46 \%$ of patients with $\mathrm{BC}$ suffer from it after BC treatment ${ }^{(1)}$.

Breast cancer-related lymphedema (BCRL) and shoulder pain are common problems and are considered as the quality of life (QOL) predictors in breast cancer patients after surgery. BCRL can cause or aggravate shoulder pain by decreasing the range of motion in the affected limb, increasing the fluid tension in the subcutaneous tissue, increasing the risk of cellulitis and other infections, increasing the risk of lymphangiosarcoma, decreasing the healing capacity in the affected tissue, and causing pathological effects on the rotator cuff tendon ${ }^{(2)}$.

Breast cancer survivors with arm lymphedema have been found to be more disabled, it can be stated that women with breast cancer-related lymphedema report poorer quality of life than breast cancer survivors without lymphedema, that's why it's important to educate breast cancer patients on the risk of lymphedema once they receive their cancer diagnosis ${ }^{(3)}$ and also have more psychological distress than do survivors without lymphedema ${ }^{(4-5)}$. In addition, women who reported swelling have reported also significantly lower quality of life with multiple functional assessments ${ }^{(6)}$. Since the disease is likely to worsen, prevention is a key element, and a series of empirical measures to reduce its onset have been proposed. The leading measures include continuing education for healthcare providers and patients, and the adoption of preventive behaviors. ${ }^{(7)}$. so it's so important to educate mastectomized patients on the risk of lymphedema once they receive their cancer diagnosis and treatment without waiting until lymphedema occur ${ }^{(3)}$. 


\section{Aims of the study}

This study aims to (1) determine the effectiveness of an instructional program on knowledge of mastectomized patients regarding lymphedema, (2) To find out relationship between patient' knowledge with some variables.

Design of the study: A quasi-experimental study

\section{Methodology}

Sample of the study: A purposive sample was selected by randomized system which consists of 60 patients was divided into two groups, experimental group consisted of (30) patients exposed to an instructional program and control group consisted of (30) patients were not exposed to the program.

Setting of the study: Al-Amal National Hospital for Management Cancer, collected from October $18^{\text {th }}, 2015$ to July $10^{\text {th }}, 2016$

Instruments: The questionnaire was constructed for the purpose of the study. The Instrumentsconsisted three parts:

\section{Part I: Socio-demographic Date Sheet:}

This part concerned with personal information of the patients including: (age, level of education, marital status, occupational status, monthly income, and residency).

\section{Part II: Clinical data of the patients:}

This part consisted of 10 items which contain: period where they had been diagnosed with the disease (in months), type of breast cancer, side of the affected breast (right, left, bilateral), stage of the breast cancer (early stage 1-2, late stage 3-4), type of treatment after diagnosis (chemotherapy, radiation therapy, both of them), kind of surgical intervention (total mastectomy, radical mastectomy), personal health history of breast cancer including past history about previous problems, breast get any of the following problems,, injuries or surgeries in the breast and family history of cancer.

\section{Part III: Mastectomized patient' knowledge regarding breast cancer related lymphedema:}

The measurement of effectiveness of an instructional program through the patients' knowledge questionnaire includes (60) items of mastectomized patients regarding lymphedema. This part was consisted of four main domains: -

1. Knowledge of mastectomized patients regarding definition, causes and risk factors of lymphatic system and breast cancer related lymphedema (10 items)

2. Knowledge of mastectomized patients regarding clinical manifestation and diagnosis of breast cancer related lymphedema (10 items)

3. Knowledge of mastectomized patients regarding treatment of breast cancer related lymphedema (10 items)

4. Knowledge of mastectomized patients regarding preventive measures of breast cancer related lymphedema (30 items)

These items were rated according to the Likers' scale; true (3); uncertain (2); false (1). The control group were given pretest \& post-Test of patient' knowledge at the same time that begiven to the study group.

Validity of the instrument: Constant validity determined for questionnaire through theuse of (22) panel experts who are faculty members from college of nursing and oncologist. The experts were asked to review the questionnaire for content with clarity. Some changes were employed according to their suggestions and valuable comments.

Reliability of the instrument: Pilot study was carried out from February $29^{\text {th }}, 2016$ to March $3^{\text {rd }}$, 2016. Ten nurses were selected from Al-Amal Hospital National for Management of Cancer. The results of the reliability present alpha correlation coefficient were $(r=0.916)$ which considered statistically acceptable.

Statistical methods:The analysis of the data was used through descriptive statistics (frequencies, percentages, and the arithmetic mean and standard deviation) and statistical inferential (T-Test\&Chi-square) in order to find the differences between the experimental group and the control group. 
Effectiveness of an Instructional Program on Knowledge of Mastectomized Patients Regard....

\section{Results}

Table 1. Distribution of Participants according to their socio-demographic data

\begin{tabular}{|c|c|c|c|c|c|c|}
\hline \multirow{2}{*}{ List } & \multirow[t]{2}{*}{ Age group (Years) } & \multicolumn{2}{|c|}{ Study Group } & \multicolumn{2}{|c|}{ Control Group } & P-value \\
\hline & & Frequency & Percent & Frequency & Percent & \multirow{7}{*}{$\begin{array}{c}\mathbf{0 . 6 3 9} \\
(\mathrm{NS})\end{array}$} \\
\hline \multirow{6}{*}{1.} & $30-39$ & 6 & 20.0 & 6 & 20.0 & \\
\hline & $40-49$ & 11 & 36.7 & 7 & 23.3 & \\
\hline & $50-59 s$ & 8 & 26.6 & 12 & 40.0 & \\
\hline & 60 and older & 5 & 16.7 & 5 & 16.7 & \\
\hline & \multirow{2}{*}{ Total } & 30 & 100.0 & 30 & 100.0 & \\
\hline & & \multicolumn{2}{|c|}{ Mean $=48.7 \pm 10.5$} & \multicolumn{2}{|c|}{ Mean $=49.2 \pm 10.5$} & \\
\hline \multirow{8}{*}{2.} & Level of Education & \multicolumn{2}{|c|}{ Study Group } & \multicolumn{2}{|c|}{ Control Group } & P-value \\
\hline & Read and Write & 2 & 6.7 & 2 & 6.7 & \multirow{7}{*}{$\begin{array}{c}0.461 \\
(\mathrm{NS})\end{array}$} \\
\hline & Elementary School & 5 & 16.7 & 11 & 36.7 & \\
\hline & Middle School & 8 & 26.7 & 7 & 23.3 & \\
\hline & High School & 4 & 13.3 & 3 & 10.0 & \\
\hline & Diploma & 7 & 23.3 & 3 & 10.0 & \\
\hline & Bachelor and above & 4 & 13.3 & 4 & 13.3 & \\
\hline & Total & 30 & 100.0 & 30 & 100.0 & \\
\hline \multirow{6}{*}{3.} & Marital Status & \multicolumn{2}{|c|}{ Study Group } & \multicolumn{2}{|c|}{ Control Group } & P-value \\
\hline & Married & 23 & 76.7 & 20 & 66.7 & \multirow{5}{*}{$\begin{array}{c}\mathbf{0 . 7 5 0} \\
(\mathrm{NS})\end{array}$} \\
\hline & Single & 3 & 10.0 & 3 & 10.0 & \\
\hline & Widowed & 3 & 10.0 & 6 & 20.0 & \\
\hline & Divorced & 1 & 3.3 & 1 & 3.3 & \\
\hline & Total & 30 & 100.0 & 30 & 100.0 & \\
\hline \multirow{6}{*}{4.} & & Study & & Contro & up & \\
\hline & Occupation & Frequency & Percent & Frequency & Percent & P-value \\
\hline & Employee & 4 & 13.3 & 8 & 26.7 & \multirow{4}{*}{$\begin{array}{c}\mathbf{0 . 0 6 0} \\
(\mathrm{NS})\end{array}$} \\
\hline & Housewife & 22 & 73.3 & 22 & 73.3 & \\
\hline & Retired & 4 & 13.3 & 0 & 0.0 & \\
\hline & Total & 30 & 100.0 & 30 & 100.0 & \\
\hline \multirow{5}{*}{5.} & Monthly Income & Study & & Contro & up & P-value \\
\hline & Insufficient & 6 & 20.0 & 8 & 26.7 & \multirow{4}{*}{$\begin{array}{c}\mathbf{0 . 4 6 8} \\
(\mathrm{NS})\end{array}$} \\
\hline & Somewhat sufficient & 13 & 43.3 & 16 & 53.3 & \\
\hline & Sufficient & 11 & 36.7 & 6 & 20.0 & \\
\hline & Total & 30 & 100.0 & 30 & 100.0 & \\
\hline \multirow{5}{*}{6.} & Residency & Study & & Contri & up & P-value \\
\hline & Urban & 21 & 70.0 & 23 & 76.7 & \multirow{4}{*}{$\begin{array}{c}\mathbf{0 . 3 5 1} \\
(\mathrm{NS})\end{array}$} \\
\hline & Suburban & 7 & 23.3 & 7 & 23.3 & \\
\hline & Rural & 2 & 6.7 & 0 & 0.0 & \\
\hline & Total & 30 & 100.0 & 30 & 100.0 & \\
\hline
\end{tabular}

Table (1) reveals that the Mean age for the study group $(48.7 \pm 10.5)$ and for the control group $(49.2 \pm$ 10.5). More than a third of the participants in the study group are in the 40-49 years-old age group $(n=11$; $36.7 \%)$, and two fifth of those in the control group are in the 50-59 years-old age group $(n=12 ; 40.0 \%)$. More than a quarter of participants in the study group are middle school graduates $(n=8 ; 26.7 \%)$, followed by those who have a diploma $(n=7 ; 23.3 \%)$. On the other hand, more than a third of participants in the control group are elementary school graduates $(\mathrm{n}=11 ; 36.7 \%)$, followed by those who are middle school graduates $(n=7$; $23.3 \%$ ).

Most of the participants in the study group are married $(n=23 ; 76.7 \%)$, and a smaller proportion of married participants in the control group $(n=20 ; 66.7 \%)$. There are equal numbers of housewives in each of the study and control groups $(n=22 ; 73.3 \%)$. More than two fifths of participants in the study group have somewhat sufficient monthly income $(n=13 ; 43.3 \%)$. For the control group, more than a half of participants also have a somewhat sufficient monthly income $(n=16 ; 53.3 \%)$.

The majority of participants in the study group have been living in urban areas $(n=21 ; 70.0 \%)$ and a larger number of participants in the control group who also live in urban areas $(n=23 ; 76.7 \%)$. Statistically, there is no significant difference between study and control groups related to the selected variables at $\mathrm{p}$-value $>$ 0.05 . 
Effectiveness of an Instructional Program on Knowledge of Mastectomized Patients Regard....

Table 2. Distribution of Participants' Clinical Characteristics

\begin{tabular}{|c|c|c|c|c|c|c|}
\hline \multirow{2}{*}{ List } & \multirow{2}{*}{ Variables } & \multicolumn{2}{|c|}{ Study Group } & \multicolumn{2}{|c|}{ Control Group } & \multirow{2}{*}{ P-value } \\
\hline & & Frequency & Percent & Frequency & Percent & \\
\hline \multirow{7}{*}{1.} & \multicolumn{5}{|l|}{ When had you been diagnosed? } & \multirow{7}{*}{$\begin{array}{l}\mathbf{0 . 8 1 5} \\
(\mathrm{NS})\end{array}$} \\
\hline & Less than month & 7 & 23.3 & 7 & 23.3 & \\
\hline & 1-3 months & 8 & 26.7 & 11 & 36.7 & \\
\hline & 4-6 months & 6 & 20.0 & 5 & 16.7 & \\
\hline & 7-9 months & 3 & 10.0 & 1 & 3.3 & \\
\hline & 10-12 months & 6 & 20.0 & 6 & 20.0 & \\
\hline & Total & 30 & 100.0 & 30 & 100.0 & \\
\hline \multirow{5}{*}{2.} & \multicolumn{5}{|c|}{ What is the type of cancer do you experience? } & \multirow{5}{*}{$\begin{array}{c}\mathbf{0 . 4 8 1} \\
(\mathrm{NS})\end{array}$} \\
\hline & Ductal carcinoma in situ & 1 & 3.3 & 1 & 3.3 & \\
\hline & Invasive Ductal Carcinoma & 27 & 90.0 & 24 & 80.0 & \\
\hline & Invasive Lobular Carcinoma & 2 & 6.7 & 5 & 16.7 & \\
\hline & Total & 30 & 100.0 & 30 & 100.0 & \\
\hline \multirow{5}{*}{3.} & Which side was the diagnosis \&n & ectomy? & & & & \multirow{5}{*}{$\begin{array}{l}\mathbf{0 . 7 3 3} \\
(\mathrm{NS})\end{array}$} \\
\hline & Right & 13 & 43.3 & 16 & 53.3 & \\
\hline & Left & 16 & 53.3 & 13 & 43.3 & \\
\hline & Both & 1 & 3.3 & 1 & 3.3 & \\
\hline & Total & 30 & 100.0 & 30 & 100.0 & \\
\hline 4. & In which stage of the cancer? & Study & oup & Con & roup & \\
\hline & First & 0 & 0.0 & 1 & 3.3 & \\
\hline & Second & 20 & 66.7 & 20 & 66.7 & 0.527 \\
\hline & Third & 10 & 33.3 & 8 & 26.7 & (NS) \\
\hline & Fourth & 0 & 0.0 & 1 & 3.3 & \\
\hline & Total & 30 & 100.0 & 30 & 100.0 & \\
\hline \multirow{5}{*}{5.} & \multicolumn{5}{|c|}{ Which type of treatment you have received after the diagnosis? } & \\
\hline & Chemotherapy & 26 & 86.7 & 25 & 83.3 & \\
\hline & Radiotherapy & 0 & 0.0 & 1 & 3.3 & $\begin{array}{c}0.600 \\
(\mathrm{NS})\end{array}$ \\
\hline & Both & 4 & 13.3 & 4 & 13.3 & \\
\hline & Total & 30 & 100.0 & 30 & 100.0 & \\
\hline & Which kind of surgery you have & erienced? & & & & \\
\hline & Total Mastectomy & 27 & 90.0 & 26 & 86.7 & 0.687 \\
\hline 6. & Radical Mastectomy & 3 & 10.0 & 4 & 13.3 & (NS) \\
\hline & Total & 30 & 100.0 & 30 & 100.0 & \\
\hline & The personal history of breast ca & & & & & \\
\hline & Existent & 5 & 16.7 & 6 & 20.0 & 0.738 \\
\hline 7. & Nonexistent & 25 & 83.3 & 24 & 80.0 & $(\mathrm{NS})$ \\
\hline & Total & 30 & 100.0 & 30 & 100.0 & \\
\hline & Did your breast get any of the fol & ing problems & & & & \\
\hline & Yes & 22 & 73.3 & 25 & 83.3 & \\
\hline 8. & No & 8 & 26.7 & 5 & 16.7 & \\
\hline & Total & 30 & 100 & 30 & 100 & \\
\hline & *If (yes), which one the following & Study & oup & Con & roup & \\
\hline & problems: & Yes & No & Yes & No & $\begin{array}{c}0.34 / \\
(\mathrm{NS})\end{array}$ \\
\hline & Inflammation of the breast tissue & $0(0.0 \%)$ & $30(100 \%)$ & $3(10 \%)$ & $27(90 \%)$ & \\
\hline 8.1 & $\begin{array}{l}\text { Abnormal discharges from the } \\
\text { nipple }\end{array}$ & $2(6.7 \%)$ & $28(93.3 \%)$ & $2(6.7 \%)$ & $28(93.3 \%)$ & \\
\hline & Breast pain & $2(6.7 \%)$ & $28(93.3 \%)$ & $3(10 \%)$ & $27(90 \%)$ & \\
\hline & Fibrosis or breast lump & $22(73.3 \%)$ & $8(26.7 \%)$ & $21(70 \%)$ & $9(30 \%)$ & \\
\hline & $\begin{array}{l}\text { Did you make any of the } \\
\text { following breast surgery? }\end{array}$ & Study & up & Con & Iroup & \\
\hline 9. & Yes & 18 & 60 & 19 & 63.3 & 0.705 \\
\hline & No & 12 & 40 & 11 & 36.7 & \\
\hline & Total & 3 & 100 & 30 & 100 & \\
\hline & *If (yes), which one the following & eries: & & & & \\
\hline & Mass or lump resection & Yes & No & Yes & No & \\
\hline 01 & & $16(53.3 \%)$ & $14(46.7 \%)$ & $\mathbf{1 7}(56.7 \%)$ & $13(43.3 \%)$ & \\
\hline 9.1 & Mastectomy & $2(6.7 \%)$ & $28(93.3 \%)$ & $3(10 \%)$ & $27(90 \%)$ & \\
\hline & $\begin{array}{l}\text { Abscess or inflammation drainage } \\
\text { from the breast }\end{array}$ & $0(0 \%)$ & $30(100 \%)$ & $0(0 \%)$ & $30(100 \%)$ & \\
\hline & $\begin{array}{l}\text { Did any of your family members } \\
\text { get cancer? }\end{array}$ & Study & oup & Con & Troup & \\
\hline 10. & Yes & 15 & 50.0 & 14 & 46.7 & 0.894 \\
\hline & No & 15 & 50.0 & 16 & 53.3 & (NS) \\
\hline & Total & 30 & 100.0 & 30 & 100.0 & \\
\hline
\end{tabular}

$*=$ The answer probably contains more than one item for each participant

Table -2- More than a quarter of participants in the study group have been diagnosed between 1-3 months $(n=8 ; 26.7 \%)$ followed by a lesser proportion for those who have been diagnosed within less than a 
month $(n=7 ; 23.3 \%)$. On the other hand, more than a third of participants in the control group have been diagnosed between $1-3$ months $(n=11 ; 36.7 \%)$ followed by those who have been diagnosed within less than a month $(n=7 ; 23.3 \%)$.

The vast majority of participants in the study group have Invasive Ductal Carcinoma $(n=27 ; 90.0 \%)$. The participants in the control group also experience Invasive Ductal carcinoma in a smaller rate $(n=24$; $80.0 \%$ ). Additionally, more than a half of participants in the study group reported that the diagnosis and mastectomy were on their left side $(n=16 ; 53.3 \%)$. The same proportion is reported by participants in the control group, but in their right side.

Most of the mastectomy surgeries had been made in the second stage of the cancer for participants in the study group $(n=20 ; 66.7 \%)$ followed by the third stage $(n=10 ; 33.3 \%)$. Consistently, most of the mastectomy surgeries have been made in the second stage for participants in the control group $(n=20 ; 66.7 \%)$ followed by the third stage $(n=8 ; 26.7 \%)$. The vast majority of participants in the study group received chemotherapy treatment after the diagnosis $(n=26 ; 86.7 \%)$, and an approximate proportion for those in the control group who also received chemotherapy $(n=25 ; 83.3 \%)$. Moreover, the vast majority of participants in the study group have experienced total mastectomy $(n=27 ; 90.0 \%)$, and an approximate of proportion for those in the control group also experienced total mastectomy $(n=26 ; 86.7 \%)$.

The majority of participants both in the study and the control groups reported that the personal history of breast cancer is nonexistent $(n=25 ; 83.3 \% ; n=24 ; 80.0 \%)$ respectively. Furthermore, most of participants both in the study and the control groups reported that they experienced fibrosis or breast lump $(n=22 ; 73.3 \% ; n$ $=21 ; 70 \%$ ) respectively.

More than a half of participants both in the study and the control groups reported that they have experienced mass or lump resection breast surgeries $(n=16 ; 53.3 \% ; n=17 ; 56.7 \%)$ respectively. Moreover, a half of participants in the study group reported that they have family member(s) who got cancer $(n=15 ; 50.0 \%)$ and this proportion is lesser for participants in the control group $(n=14 ; 46.7 \%)$.

Statistically, there is no significant difference between study and control groups related to the selected variables at $p$-value $>0.05$.

Table 3. Comparison of Participants' Knowledge score between The Study and Control Groups at Pre-Post Test

\begin{tabular}{|l|c|c|c|c|c|c|}
\hline \multirow{3}{*}{ Group } & \multicolumn{5}{|c|}{ Pre-Test } & \multicolumn{3}{|c|}{ Post-Test } \\
\cline { 2 - 7 } & Low & Moderate & High & Low & Moderate & High \\
\cline { 2 - 6 } & $\mathbf{f ( \% )}$ & $\mathbf{f}(\boldsymbol{\%})$ & $\mathbf{f}(\boldsymbol{\%})$ & $\mathbf{f}(\mathbf{\%})$ & $\mathbf{f}(\boldsymbol{\%})$ & $\mathbf{f}(\mathbf{\%})$ \\
\hline Study & $\mathbf{0 ( 0 . 0 \% )}$ & $\mathbf{1 9}(63.3 \%)$ & $\mathbf{1 1}(36.7 \%)$ & $0(0.0 \%)$ & $0(0.0 \%)$ & $\mathbf{3 0}(100 \%)$ \\
\hline Control & $2(6.4 \%)$ & $\mathbf{2 1}(70.0 \%)$ & $\mathbf{7}(23.3 \%)$ & $4(13.3 \%)$ & $\mathbf{2 6}(86.7 \%)$ & $0(0.0 \%)$ \\
\hline P-value & \multicolumn{5}{|c|}{$0.224(\mathrm{NS})$} & $\mathbf{0 . 0 0 0}(\mathbf{H S})$ \\
\hline
\end{tabular}

In this table, there were significant differences between participants' Knowledge score of Pre and Post-Test among study and control groups at p-value $<0.01$.

Table 4. Comparison Significant Between the Two Period (Pre and Post-Test) Related toPatients' Knowledge of the Study and Control Groups

\begin{tabular}{|c|c|c|c|c|c|c|c|c|}
\hline \multirow{3}{*}{ Main Domains of Knowledge } & \multicolumn{2}{|c|}{ Study } & \multirow{3}{*}{ T-Test } & \multirow{3}{*}{$\mathbf{P}<\mathbf{0 . 0 1}$} & \multicolumn{2}{|c|}{ Control } & \multirow{3}{*}{$\begin{array}{l}\text { T- } \\
\text { Test }\end{array}$} & \multirow{3}{*}{$\mathbf{P}>\mathbf{0 . 0 5}$} \\
\hline & Pre & Post & & & Pre & Post & & \\
\hline & $\begin{array}{l}\text { Mean } \\
+ \text { SD }\end{array}$ & $\begin{array}{c}\text { Mean } \\
+ \text { SD }\end{array}$ & & & $\begin{array}{l}\text { Mean } \\
+ \text { SD }\end{array}$ & $\begin{array}{c}\text { Mean } \\
+ \text { SD }\end{array}$ & & \\
\hline $\begin{array}{l}\text { Overall knowledge related to definition, } \\
\text { causes, and risk factors of lymphedema }\end{array}$ & $\begin{array}{c}2.08 \pm \\
0.3\end{array}$ & $\begin{array}{l}2.76 \pm \\
0.2\end{array}$ & $10 . \overline{461}$ & HS & $\begin{array}{l}2.12 \pm \\
0.3\end{array}$ & $\begin{array}{l}2.10 \\
\pm 0.3\end{array}$ & 0.259 & NS \\
\hline $\begin{array}{l}\text { Patients' knowledge related to the } \\
\text { symptoms and diagnosis of lymphedema }\end{array}$ & $2.01 \pm 0.3$ & $\begin{array}{c}2.64 \pm \\
0.2\end{array}$ & -9.692 & HS & $\begin{array}{l}2.02 \\
\pm 0.3\end{array}$ & $\begin{array}{l}2.03 \\
\pm 0.2\end{array}$ & $\overline{0.153}$ & NS \\
\hline $\begin{array}{l}\text { Patients' knowledge related to } \\
\text { management of lymphedema }\end{array}$ & $\begin{array}{c}2.15 \pm \\
0.3\end{array}$ & $\begin{array}{l}2.74 \pm \\
0.3\end{array}$ & -7.662 & HS & $\begin{array}{l}2.17 \pm \\
0.3\end{array}$ & $\begin{array}{l}2.18 \\
\pm 0.3\end{array}$ & $\overline{0.153}$ & NS \\
\hline $\begin{array}{l}\text { Patients' knowledge related to prevention } \\
\text { of lymphedema }\end{array}$ & $\begin{array}{c}2.25 \pm \\
0.3\end{array}$ & $\begin{array}{c}2.84 \pm \\
0.9\end{array}$ & -3.430 & HS & $\begin{array}{l}2.03 \pm \\
0.6\end{array}$ & $\begin{array}{l}2.25 \\
\pm 0.3\end{array}$ & $\begin{array}{c}- \\
1.818\end{array}$ & NS \\
\hline Overall Domains & $2.12 \pm .21$ & $\begin{array}{c}2.74 \\
\pm 0.14\end{array}$ & $13 . \overline{777}$ & HS & $\begin{array}{c}2.14 \\
\pm 0.22\end{array}$ & $\begin{array}{c}2.07 \\
\pm 0.29\end{array}$ & 1.060 & NS \\
\hline
\end{tabular}

Table - 4- shows that there were highly significant differences between study and control groups of main domains ofknowledgeat $\mathrm{p}<0.01$. 
Table 5. Association between Participants' Socio-Demographic and Clinical Characteristics and their Overall Knowledge of the Study Group

\begin{tabular}{|c|c|c|c|c|c|}
\hline \multirow[t]{2}{*}{ Model } & \multicolumn{2}{|c|}{ Unstandardized Coefficients } & \multirow{2}{*}{$\begin{array}{c}\begin{array}{c}\text { Standardized } \\
\text { Coefficients }\end{array} \\
\text { Beta }\end{array}$} & \multirow[t]{2}{*}{$\mathbf{t}$} & \multirow[t]{2}{*}{ Sig. } \\
\hline & B & Std. Error & & & \\
\hline Age & -.111 & .183 & -.166 & -.608 & .552 \\
\hline Level of Education & .492 & 1.290 & .110 & .382 & .708 \\
\hline Marital Status & .414 & 2.486 & .050 & .166 & .870 \\
\hline Occupation & -2.213 & 1.635 & -.373 & -1.354 & .196 \\
\hline Monthly Income & -2.944 & 2.686 & -.324 & -1.096 & .290 \\
\hline Residency & -1.045 & 3.114 & -.095 & -.336 & .742 \\
\hline Duration of diagnosis & -.324 & 1.625 & -.070 & -.200 & .845 \\
\hline Type of cancer & -2.461 & 4.075 & -.165 & -.604 & .555 \\
\hline Side of the diagnosis and mastectomy & 1.824 & 4.399 & .151 & .415 & .684 \\
\hline The stage of the cancer in which was the mastectomy & -4.304 & 5.559 & -.304 & -.774 & .451 \\
\hline The type of received treatment after the diagnosis & -3.285 & 3.437 & -.335 & -.956 & .354 \\
\hline The kind of surgery & 2.376 & 6.097 & .107 & .390 & .702 \\
\hline The personal history of breast cancer & -1.429 & 6.617 & -.080 & -.216 & .832 \\
\hline Having a family member with cancer & -1.486 & 4.218 & -.111 & -.352 & .729 \\
\hline
\end{tabular}

This table shows that there is no association between participants' socio-demographic and clinical characteristics and their overall knowledge in the study group.

\section{Discussion}

More than a third of the participants in the study group are in the $40-49$ years-old age group (36.7\%), and two fifth of those in the control group are in the 50-59 years-old age group (40.0\%). More than a quarter of participants in the study group are middle school graduates $(26.7 \%)$, followed by those who have a diploma $(23.3 \%)$. On the other hand, more than a third of participants in the control group are elementary school graduates $(36.7 \%)$, followed by those who are middle school graduates (23.3\%). Most of the participants in the study and control groups are married. There are equal numbers of housewives in each of the study and control groups $(73.3 \%)$. More than two fifths of participants in the study group have somewhat sufficient monthly income $(43.3 \%)$ and half of participants also have a somewhat sufficient monthly income in the control group (53. 3\%).The majority of participants in the study and control groups have been living in urban areas (table 1).

This totally agree with a study published on the incidence of breast cancer among Iraqi women stated that about one-third of the diagnosed patients were between $40-49$ years old ${ }^{(8)}$, Ibrahim, found that, the most of the sample $(26 \%)$ were elementary school graduates and housewives ${ }^{(9)}$. Alwan, which found that the majority of the sample in their studies (more than $70 \%$ ) were married ${ }^{(10)}$.Urban living increased breast cancer rates by the same margins of three to four times when compared to rural environments ${ }^{(11-12)}$.

More than a quarter of participants in the study group have been diagnosed between 1-3 months (26.7\%) followed by a lesser proportion for those who have been diagnosed within less than a month $(23.3 \%)$. On the other hand, more than a third of participants in the control group have been diagnosed between 1-3 months $(36.7 \%)$ followed by those who have been diagnosed within less than a month $(23.3 \%)$.

The vast majority of participants in the study group have Invasive Ductal Carcinoma (90.0\%). The participants in the control group also experience Invasive Ductal carcinoma in a smaller rate $(80.0 \%)$. Additionally, more than a half of participants in the study group reported that the diagnosis and mastectomy were on their left side $(53.3 \%)$. The same proportion is reported by participants in the control group, but in their right side. Most of the mastectomy surgeries had been made in the second stage of the cancer for participants in the study group $(66.7 \%)$ followed by the third stage $(33.3 \%)$. Consistently, most of the mastectomy surgeries have been made in the second stage for participants in the control group (66.7\%) followed by the third stage $(26.7 \%)$. The vast majority of participants in the study group received chemotherapy treatment after the diagnosis (86.7\%), and an approximate proportion for those in the control group who also received chemotherapy $(83.3 \%)$. Moreover, the vast majority of participants in the study group have experienced total mastectomy (90.0\%), and an approximate of proportion for those in the control group also experienced total mastectomy (86. 7\%).The majority of participants both in the study and the control groups reported that the personal history of breast cancer is nonexistent $(83.3 \%$; 80.0\%) respectively. Furthermore, most of participants both in the study and the control groups reported that they experienced fibrosis or breast lump $(73.3 \% ; 70 \%)$ respectively. More than a half of participants both in the study and the control groups reported that they have experienced mass or lump resection breast surgeries $(53.3 \%$; 56.7\%) respectively. Moreover, a half of participants in the study group reported that they have family member(s) who got cancer $(50.0 \%)$ and this proportion is lesser for participants in the control group (46.7\%) (Table 2). Wang, were focusing on explaining the variations of late stage diagnosis of breast cancer and its effect ${ }^{(13)}$. In one of the WHO ${ }^{(14)}$ reports, the results estimated the most common histological type determined by microscopic examination revealed that the 
dominant type of breast cancer was invasive ductal carcinoma. Shahpar, ${ }^{(15)}$ were $(67.5 \%)$ of the participants who diagnosed with stage II breast cancer followed by $(24.4 \%)$ diagnosed with late stages of the diseases, with Randheer, ${ }^{(16)}$ when reported that about $92 \%$ of patients in their study received neoadjuvant and adjuvant chemotherapy and post-operative radiotherapy. Ibrahim, stated that the highest percentage of the study sample were having negative previous problems in the breast and $(30 \%)$ of the sample were having family history of breast cancer ${ }^{(9)}$.

Our study revealed that there were significant differences between participants' knowledge score of Pre and Post-Test among study and control groups at $\mathrm{p}$-value $<0.01$. (Table 3 ). Cho, documented in their results that a significant effect of education on cancer knowledge scores, $\mathrm{p}<0.0001^{(17)}$.

The researcher confirmed that there were highly significant differences between study and control groups at post-test in overall main domains (Table 4) Aly, revealed that, after implementing of health educationintervention, there were a significant improvement and increase in studied women among all of them about arm lymphedema post mastectomy and prevention strategies ${ }^{(18)}$.

The findings of our study, show that there was no significant relationship between demographic characteristics of the participants and their overall knowledge in the study group (Table 5). Borman, reported in their results that there was not any association between the sample who received information concerning with breast cancer related lymphedema and their demographic and clinical characteristics in regard to lymphedema education $^{(19)}$.

\section{Conclusion}

The study concluded that the effectiveness of an Instructional program regarding patient s' knowledge concerning lymphedema of breast cancer is a positive at a highly significant rate.

\section{Recommendations}

- After diagnosing the patients, an instructional program about breast cancer and most related complications especially secondary lymphedema, should be implemented to reduce the complications and patients fear as much as possible and to raise their awareness toward the early symptoms of the BCRL.

- Special education program should be carried out for the medical staff and specifically for the nurses who are working with breast cancer patients in the oncology centers and if possible in the surgical words too, to raise their awareness toward one of the most important complications of the breast cancer and the surgery which is BCRL.

- Manual or booklet of instructions about BCRL and its prevention should be published and delivered to breast cancer patients who underwent mastectomy as a guidance.

\section{Acknowledgements}

I would like to express my sincere appreciation for all of those who have support and help me through my journey in this life and be there for me, especially to the Prof. Dr. Wafa Mohammed Attoof, my supervisor, for positive response to my query supervision. For generously sharing her scientific knowledge and giving me continuous encouragement and support. Special thanks and appreciation to Instructor Prof. Dr.MohammedBaqer Habeeb Abd Ali for his encouragement, support and help in this thesis. Of course I can't forget Dr. Asaad Ismail, who gave the hope for better tomorrow and encourage me to keep going in my life.Finally, the last but not the least, my deep thanks and respect to the patients who participated in the present study despite of their suffering.

\section{References}

[1]. Soran A, Wu WC, Dirican A, JohnsonR, Andacoglu O, \& Wilson J: Estimating the Probability of Lymphedema After Breast Cancer Surgery,American Journal of Clinical Oncology, October 2011;34(5), 506-510.

[2]. Jang D, Kim M, Oh S, \& Kim J: 'The Influence of Arm Swelling Duration on Shoulder Pathology in Breast Cancer Patients with Lymphedema', Plos ONE, 2015; 10 (11), 1-7, Academic Search Complete, EBSCOhost, viewed 1 January 2016.

[3]. Kela:lymfaterapia,[Online], 2015; Available from: http://www.kela.fi/lymfaterapia Accessed 23.4.2015

[4]. PyszelA, Malyszczak K, Pyszel K, Andrzejak R\& Szuba A: DISABILITY, PSYCHOLOGICAL DISTRESS AND QUALITY OF LIFE IN BREAST CANCER SURVIVORS WITH ARM LYMPHEDEMA,Lymphology,2006;39(4), 185-192.

[5]. Ridner SH: Quality of life and a symptom cluster associated with breast cancer treatment-related lymphedema,Support Care Cancer, 2005;13(11), 904-911.

[6]. Paskett ED, Naughton MJ, McCoy TP, Case LD\& Abbott JM: The Epidemiology of Arm and Hand Swelling in Premenopausal Breast Cancer Survivors, Cancer Epidemiol Biomarkers Prev,2007; 16(4), 775-782.

[7]. Larouche K, \& Witty MF: Treatment of cancer-related Secondary Lymphedema,INESSS LE SAVOUR PREND FORME, April 2011; 7(3), 14-17

[8]. Science Daily:Breast cancer incidence among Iraqi women profiled,2010;[Online] [Accessed 6 July 2016] available from:https://www.sciencedaily.com/releases/2010/03/100311074127.htm

[9]. Ibrahim NA: Impact of Instructional Intervention Program upon Women's Physical and Psychological Health Status Who Undergo Chemotherapy after Mastectomy, Iraqi National Journal of Nursing Specialties, 2011; Vol. 25, Special issue: 91 - 106.

[10]. Alwan N: breast cancer demographic characteristics and clinico-pathological presentation of patients in Iraq, journal breast cancer, 2010; 16(11): 1159-1163 
[11]. Nagrani RT, Budukh A, Koyande S, Panse NS, Mhatre SS\& Badwe R:Rural urban differences in breast cancer in India,Indian Journal of Cancer, July-September 2014; 51(3), 277-281.

[12]. Dey S, Soliman AS, Hablas A, Seifeldein IA, Ismail K, Ramadan M, El-Hamzawy H, Wilson ML, Banerjee M, Boffetta P, Harford $\mathrm{J}$ and MerajverSD:Urban women face higher breast cancer rates. 2010;[Online] [Accessed 2015]. Available fromhttp://www.environmentalhealthnews.org/ehs/newscience/egypt-urban-women-higher-breast-cancer-than-rural

[13]. Wang J, Costantino J, Tan-Chiu E, Wickerham D, Paik S \&Wolmark N: Lower-category benign breast disease and the risk of invasive breast cancer,Journal National Cancer Inst, 2004; 96(8), 616-620.

[14]. Sinn H-P \& Kreipe H: Abrief overview of the WHO classification of breast tumors, $4^{\text {th }}$ edition, focusing on issues and updates from the $3^{\text {rd }}$ edition. Breast Care. 2013; 8. p.149-154.

[15]. Shahpar H, Atieh A, Maryam A, Fatemeh HS, Massoome N, brahimiMandana \& Esmaeil, AM: Risk Factors of Lymph Edema in Breast Cancer Patients, International Journal of Breast Cancer, 2013; pp.1-7 [Online] Available from: http://dx.doi.org/10.1155/2013/641818 , Last Revised: 19 may 2013

[16]. Randheer S, Kadambari D, Srinivasan K, Bhuvaneswari V, Bhanumathy M \&Salaja R: Comprehensive decongestive therapy in postmastectomy lymphedema: An Indian perspective. Indian Journal of Cancer, October-December, 2011; 48(4),397-402. doi: 10.4103/0019-509X.92250

[17]. Cho HS, Michelle, Davis GC, Paek JL, Rao R, Zhao H, Xie, Xian-Jin, Yousef MG, Fedric T, Euhus DH, \& Leitch H: A randomised trial of nursing interventions supporting recovery of the postmastectomy patient, Journal of Clinical Nursing,2012; 22(1), 919-929.

[18]. Aly SA, Abd-Allah ES, Ali SA \& EL-Sawy WH: Improving Quality of Life for Women with Arm Lymphedema Post Mastectomy in Zagazig City, Australian Journal of Basic and Applied Sciences, 2012; 6(3), 428-442.

[19]. Borman P, Yaman A, Yasrebi S \& Özdemir O: The importance of education on breast cancer related lymphedema. Journal of Cancer Education,2016;pp. 1-5.DOI: 10.1007/s13187-016-1026-1 